\title{
Esophageal motility disorders in patients with gastro-esophageal reflux disease diagnosed by using high resolution esophageal manometry- data from the developing world
}

\author{
Zain Majid', Syed Mudassir Laeeq ${ }^{2}$, Muhammad Manzoor ul Haq ${ }^{3}$, Farina M Hanif ${ }^{4}$, \\ Shoaib Ahmed Khan ${ }^{5}$, Abbas Ali Tasneem ${ }^{6}$, Nasir Hassan Luck ${ }^{7}$ \\ ${ }^{1}$ Consultant, ${ }^{2,4,6}$ Associate Professor, ${ }^{5}$ Registrar, ${ }^{3}$ Assistant Professor, ${ }^{7}$ Professor, Department of Gastroenterology, \\ Sindh Institute of Urology and Transplantation, SIUT, Karachi, Pakistan
}

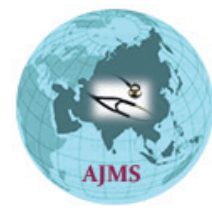

A B S TR A C T

Background: Gastro-esophageal reflux disease (GERD) has a prevalence of $10-20 \%$ in the Western countries while its prevalence amongst the Pakistani population is between 22 to $24 \%$. Esophageal manometry is currently the gold standard for diagnosing esophageal motility disorders. Aims and Objectives: To determine the frequency of esophageal motility disorder in patients with GERD. Materials and Methods: This cross-sectional study was conducted at the department of Hepatogastroenterology, Sindh Institute of Urology and Transplantation, Karachi, Pakistan. Patients diagnosed with GERD (defined as having typical reflux symptoms with more than 2 episodes per were) were included in this study. These patients were subjected to upper $\mathrm{Gl}$ endoscopy followed by esophageal manometry. Esophageal motility disorders were then classificated by using the Chicago classification 3.0. Results: A total of 76 patients were included in our study, out of which $41(53.9 \%)$ were females. A mean age of 46.1 years \pm 12 years and a mean body mass index (BMI) of $23.7 \mathrm{~kg} / \mathrm{m} 2$ was noted. The most common comorbid condition seen in our patients was diabetes mellitus, which was seen in 13 patients (17\%). A normal EGD was noted in 48 patients $(63 \%)$. Liquid perfusion esophageal manometer catheter was mainly used in our study that is in 70 patients $(92.1 \%)$. Weak esophageal peristalsis was the most common esophageal motor abnormality seen in 16 patients $(21.1 \%)$. Conclusion: A significant proportion of patients with GERD have the presence of a motility disorders, the early identification and treatment of which can lead to improvement GERD symptoms.

Key words: Gastroesophageal reflux disease; Esophageal; Manometry; Esophageal Motility disorders

\section{INTRODUCTION}

Gastroesophageal reflux disease (GERD) is defined as distressing symptoms or complications that result from the reflux of stomach contents. ${ }^{1}$ This disease may have a typical or atypical presentation. In the typical form, its principal symptoms are retrosternal burning sensation and regurgitation, while in the atypical form, the patient presents mainly with extra-esophageal symptoms like cough, laryngitis, and asthma. Patients with GERD may present for the first time with chest pain. ${ }^{2,3}$ According to Dent et al., ${ }^{4}$ the prevalence of GERD is around 10 to $20 \%$ worldwide, while studies were done in Pakistan reveal its prevalence to be between $24 \%$ to $35 \% .5,6$

Forty to $50 \%$ of patients with GERD have abnormal peristaltic activity, while a severe dysmotility is seen in $20 \% .^{7}$ Currently, no data is available regarding the frequency of esophageal motility disorders (EMD) in patients with GERD is available in Pakistan, hence the aim 
of this study was to find out the frequency of esophageal motility disorders in patients with GERD, diagnosed based on Chicago classification by using the High-resolution manometry (HRM). Since environmental, lifestyle factors (like the consumption of tea, coffee, soft drinks, alcohol, spicy food, having a high BMI, smoking) and genetic factors are known risk factors for GERD, its frequency might vary locally depending upon the number of factors that are present.

\section{AIMS AND OBJECTIVE}

To determine the frequency of esophageal motility disorders in patients with GERD.

\section{MATERIALS AND METHODS}

This cross-sectional study was conducted at the department of Hepatogastroenterology, Sindh Institute of Urology and Transplantation, Karachi, Pakistan, from May 2018 until March 2019. Patients diagnosed with GERD (defined as having typical reflux symptoms with more than two episodes per week were included in this study), and a total of 76 patients with GERD were selected. Data was collected from the outpatients' department of the Hepatogastroenterology unit, Sindh Institute of Urology and Transplantation (SIUT) Karachi, Pakistan, after taking permission from the ethical review committee. Before the collection procedure, informed written consent was taken from all the participants. All the included cases will be subjected to endoscopic evaluation to rule out mechanical obstruction before being subjected to manometry. The subjects then underwent an upper gastrointestinal endoscopy (UGI) followed by Highresolution esophageal manometry two hours later. For the esophageal manometry procedure, topical anesthesia was used to sedate the patients, and the small flexible manometry tube was inserted via the nose into the esophagus and the stomach. Sensors located on the tube recorded the various parameters, and then the patient was asked to sip a small amount of water, following which the functions of the sphincters were assessed. The whole procedure lasted for around 15 minutes, with the patient being discharged on the same day. The following variables were noted during the manometric evaluation: Distal Contractile Integral (DCI), Contractile Front Velocity (CFV), Peristalsis Breaks, Distal Latency (DL), Bolus head velocity, Bolus minimum velocity, Bolus tail velocity, Lower esophageal sphincter (LES) Upper border, LES IRP, LES Intraabdominal length, Upper esophageal sphincter (UES) Upper border, UES IRP, Peristaltic integrity, Contraction pattern and the Intrabolus pressure pattern. Data entry and analysis were done using IBM Statistical Program for Social Sciences Program (SPSS) version 20.0. For categorical variables like gender, co-morbidity frequencies and percentages were calculated. For continuous variables like weight, height and BMI, mean and standard deviation were calculated. Stratification would be applied to compare the types of motility disorders with the following: gender, BMI and duration of symptoms.

\section{RESULTS}

Seventy-six patients diagnosed with GERD underwent EGD followed by esophageal manometry, out of which $41(53.9 \%)$ were females while $35(46.1 \%)$ were males. Mean age of 46.1 years \pm 12 years was noted. The mean height was $166 \mathrm{~cm}$, with a mean weight of $65.7 \mathrm{~kg}$ and a mean BMI of $23.7 \mathrm{~kg} / \mathrm{m} 2$ (Table 1). The most common comorbid condition noted in our patients was diabetes mellitus, seen in 13 patients (17\%), followed by hypertension in 10 patients $(13.2 \%)$, ischemic heart disease in $4(5.3 \%)$, renal stone disease in $2(2.6 \%)$, renal abscess in $2(2.6 \%)$, joint disease in $1(1.3 \%)$, bipolar disorder $1(1.3 \%)$. One patient $(2.6 \%)$ had a previous history of renal transplantation, while $42(55.3 \%)$ patients had no prior comorbid conditions.

The majority of the participants in our study were married $64(84.2 \%)$, while $12(15.8 \%)$ of the patients were single.

A normal EGD was seen in 48 patients (63\%), followed by a gaping lower esophageal sphincter (LES) noted in 7 cases $(9.2 \%)$. Achalasia was suspected in 9 patients $(11.8 \%)$, pangastric erythema was noted in $5(6.6 \%)$, antral erythema in 4 patients $(5.3 \%)$, antral erosions in $1(1.3 \%)$, and distal esophagitis were seen in 1 case $(1.3 \%)$. The mean $Z$ line was noted at $38 \mathrm{~cm}$ in 32 patients $(42 \%)$. A liquid perfusion probe was mainly used in our 70 patients $(92.1 \%)$, while a solid-state catheter was used in 6 cases $(7.9 \%)$.

Based upon the Chicago classification 3.0, the most common motility disorder noted in these patients were as follow (Figure 1): Weak peristalsis was noted in 16 cases $(21.1 \%)$, followed by aperistalsis, which was seen in 8 patients $(10.5 \%)$, frequent failure of peristalsis

\begin{tabular}{lc}
\multicolumn{2}{l}{ Table 1: Baseline demographic characteristics } \\
\hline Characteristic & Frequency \\
\hline Gender & Females $41(53.9 \%)$ \\
& Males $35(46.1 \%)$ \\
Mean age, years & $46 \pm 12$ \\
Mean weight, $\mathrm{kg}$ & $65.7 \pm 11$ \\
Mean height, $\mathrm{cm}$ & $166 \pm 9$ \\
Mean BMl, $\mathrm{kg} / \mathrm{m}^{2}$ & $23.7 \pm 3$ \\
Mean Z line,cm & $38 \pm 2$ \\
\hline
\end{tabular}


in $5(6.6 \%)$, the rapid contraction was seen in $3(3.9 \%)$, GEJ obstruction in 3 cases (3.9\%), esophageal spasm in $3(3.9 \%)$. A DCI of more than $5000 \mathrm{mmHg}$ suggestive of nutcracker esophagus was seen in $3(3.9 \%)$, while a DCI of more than $8000 \mathrm{mmHg}$ confirming jackhammer esophagus was found in 1 patient $(1.3 \%)$. An IRP less than $15 \mathrm{~mm} \mathrm{Hg}$ suggestive of achalasia was noted in 8 cases $(10.5 \%)$, this was later subsequently confirmed via a barium swallow. While $22(28.9 \%)$ who could not be adjusted according to the Chicago classification were labeled as unclassified. A normal manometric profile was seen in 4 patients $(5.3 \%)$. Stratification was applied between the types of motility disorders with gender, BMI and duration of symptoms. (Tables 2-4) After applying stratification, a significant $\mathrm{p}$-value $(0.022)$ was seen between rapid contraction and BMI, however, this could be due to the protective effect of those patients who did not have rapid contraction but had either a high or low BMI.

\section{DISCUSSION}

Ineffective esophageal motility is the most common esophageal motor disorder that is seen in patients with GERD. ${ }^{8}$ While the most common motility disorder seen in our study was weak peristalsis reported in 16 patients. $(21.1 \%)$

Ribolsi et al., found that only $24 \%$ of the patients with GERD had evidence of an esophageal dysmotility. While in our case, only five patients out of $76(5.3 \%)$ the patients with GERD had a normal manometric profile.

Deepalakshmi et al., ${ }^{10}$ subjected 66 patients with GERD to esophageal manometry, while our study involved 76 patients. The majority of the participants in our study were females with 41 patients $(53.9 \%)$, while study reported by Deepalakshmi et al., observed the majority were males 42 patients (64\%). The mean age in our

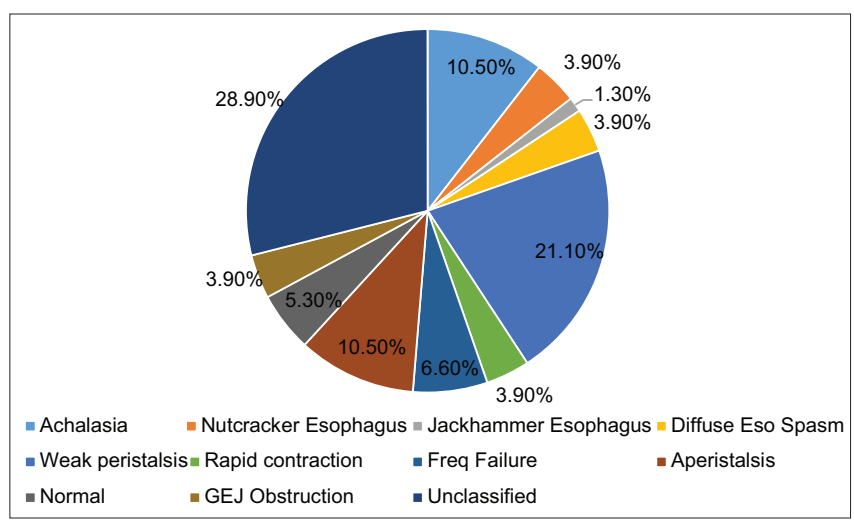

Figure 1: Frequency of esophageal motility disorders in our patient population study was $46.6 \pm 12$ years, while the Deepalakshmi et al., reported a mean age of $40.8 \pm 12$ years. The most common esophageal motility disorder in the current study was weak peristalsis, while Deepalakshmi et al., found ineffective esophageal motility to be the most common esophageal motility disorder in patients with GERD. ${ }^{10}$

Achalasia can be seen in patients with GERD and might be a protective response of the esophagus against reflux. ${ }^{11}$

\begin{tabular}{|c|c|c|c|c|}
\hline \multirow{2}{*}{\multicolumn{2}{|c|}{$\begin{array}{l}\text { Esophageal Motility } \\
\text { disorder according to } \\
\text { chicago classification }\end{array}$}} & \multicolumn{2}{|c|}{ Gender } & \multirow[t]{2}{*}{ P-value } \\
\hline & & \multirow{2}{*}{$\begin{array}{c}\text { Male } \\
7(9.2 \%)\end{array}$} & \multirow{3}{*}{$\begin{array}{c}\text { Female } \\
3(4.0 \%) \\
38(50 \%)\end{array}$} & \\
\hline Achalasia & Yes & & & 0.099 \\
\hline & No & $28(36.8 \%)$ & & \\
\hline Weak & Yes & $7(9.2 \%)$ & $9(11.8 \%)$ & 0.797 \\
\hline peristalsis & No & $28(36.8 \%)$ & $32(42.1 \%)$ & \\
\hline \multirow[t]{2}{*}{ Aperistalsis } & Yes & $4(5.2 \%)$ & $4(5.2 \%)$ & 0.780 \\
\hline & No & $31(40.8 \%)$ & $37(48.7 \%)$ & \\
\hline \multirow{2}{*}{$\begin{array}{l}\text { Frequent } \\
\text { failure }\end{array}$} & Yes & $3(4.0 \%)$ & $2(2.6 \%)$ & 0.648 \\
\hline & No & $32(42.1 \%)$ & $39(51.3 \%)$ & \\
\hline \multirow[t]{2}{*}{ Jackhammer } & Yes & $1(1.32 \%)$ & $0(0 \%)$ & 0.461 \\
\hline & No & $34(44.7 \%)$ & $41(53.9 \%)$ & \\
\hline \multirow{2}{*}{$\begin{array}{l}\text { Nutcracker } \\
\text { esophagus }\end{array}$} & Yes & $1(1.3 \%)$ & $2(2.6 \%)$ & 0.560 \\
\hline & No & $34(44.7 \%)$ & $39(51.3 \%)$ & \\
\hline \multirow{2}{*}{$\begin{array}{l}\text { GEJ } \\
\text { obstruction }\end{array}$} & Yes & $1(1.3 \%)$ & $2(2.6 \%)$ & 0.560 \\
\hline & No & $34(44.7 \%)$ & $39(51.3 \%)$ & \\
\hline \multirow{2}{*}{$\begin{array}{l}\text { Rapid } \\
\text { contraction }\end{array}$} & Yes & $0(0 \%)$ & $3(4.0 \%)$ & 0.152 \\
\hline & No & $35(46.0 \%)$ & $38(50.0 \%)$ & \\
\hline \multirow{4}{*}{$\begin{array}{l}\text { Esophageal } \\
\text { Spasm } \\
\text { Unclassified }\end{array}$} & Yes & $0(0 \%)$ & $3(4.0 \%)$ & 0.152 \\
\hline & No & $35(46.0 \%)$ & $38(50 \%)$ & \\
\hline & Yes & $10(13.1 \%)$ & $12(15.7 \%)$ & 0.466 \\
\hline & No & $26(34.2 \%)$ & $28(36.8 \%)$ & \\
\hline
\end{tabular}

\begin{tabular}{|c|c|c|c|c|}
\hline \multirow{2}{*}{\multicolumn{2}{|c|}{$\begin{array}{l}\text { Esophageal motility } \\
\text { disorder according to } \\
\text { chicago classification }\end{array}$}} & \multicolumn{2}{|c|}{ BMI $\left(\mathrm{kg} / \mathrm{m}^{2}\right)$} & \multirow[t]{2}{*}{ P-value } \\
\hline & & $<25$ & $>25$ & \\
\hline \multirow[t]{2}{*}{ Achalasia } & Yes & $7(9.2 \%)$ & $3(4.0 \%)$ & 0.601 \\
\hline & No & $47(61.8 \%)$ & $19(25.0 \%)$ & \\
\hline \multirow{2}{*}{$\begin{array}{l}\text { Weak } \\
\text { peristalsis }\end{array}$} & Yes & $12(15.7 \%)$ & $4(5.3 \%)$ & 0.656 \\
\hline & No & $42(55.3 \%)$ & $18(23.7 \%)$ & \\
\hline \multirow[t]{2}{*}{ Aperistalsis } & Yes & $5(6.6 \%)$ & $3(4.0 \%)$ & 0.461 \\
\hline & No & $49(64.5 \%)$ & $19(25.0 \%)$ & \\
\hline \multirow{2}{*}{$\begin{array}{l}\text { Frequent } \\
\text { failure }\end{array}$} & Yes & $3(4.0 \%)$ & $2(2.6 \%)$ & 0.453 \\
\hline & No & $51(67.1 \%)$ & $20(26.3 \%)$ & \\
\hline \multirow[t]{2}{*}{ Jackhammer } & Yes & $1(1.31 \%)$ & $0(0 \%)$ & 0.711 \\
\hline & No & $53(69.7 \%)$ & $22(28.9 \%)$ & \\
\hline \multirow{2}{*}{$\begin{array}{l}\text { Nut cracker } \\
\text { esophagus }\end{array}$} & Yes & $1(1.3 \%)$ & $2(2.6 \%)$ & 0.199 \\
\hline & No & $53(69.7 \%)$ & $20(26.3 \%)$ & \\
\hline \multirow{2}{*}{$\begin{array}{l}\text { GEJ } \\
\text { obstruction }\end{array}$} & Yes & $2(2.6 \%)$ & $1(1.3 \%)$ & 0.647 \\
\hline & No & $52(68.4 \%)$ & $21(27.6 \%)$ & \\
\hline \multirow{2}{*}{$\begin{array}{l}\text { Rapid } \\
\text { contraction }\end{array}$} & Yes & $0(0 \%)$ & $3(4.0 \%)$ & 0.022 \\
\hline & No & $54(71.0 \%)$ & $19(25.0 \%)$ & \\
\hline \multirow{4}{*}{$\begin{array}{l}\text { Esophageal } \\
\text { Spasm } \\
\text { Unclassified }\end{array}$} & Yes & $1(1.3 \%)$ & $2(2.6 \%)$ & 0.199 \\
\hline & No & $53(69.7 \%)$ & $20(26.3 \%)$ & \\
\hline & Yes & $18(23.7 \%)$ & $3(4.0 \%)$ & 0.69 \\
\hline & No & $36(47.3 \%)$ & $19(25.0 \%)$ & \\
\hline
\end{tabular}




\begin{tabular}{|c|c|c|c|c|}
\hline \multirow{2}{*}{\multicolumn{2}{|c|}{$\begin{array}{l}\text { Esophageal Motility } \\
\text { Disorder according to } \\
\text { Chicago classification }\end{array}$}} & \multicolumn{2}{|c|}{ Duration of symptoms } & \multirow{3}{*}{$\begin{array}{c}\text { P value } \\
0.346\end{array}$} \\
\hline & & \multirow{2}{*}{$\begin{array}{c}\begin{array}{c}\text { Less than } \\
\text { 2 weeks }\end{array} \\
5(6.6 \%)\end{array}$} & \multirow{2}{*}{$\begin{array}{c}\text { More than } \\
\text { 2 weeks }\end{array}$} & \\
\hline Achalasia & $\begin{array}{l}\text { Yes } \\
\text { No }\end{array}$ & & & \\
\hline Weak peristalsis & $\begin{array}{l}\text { Yes } \\
\text { No }\end{array}$ & $\begin{array}{c}4(5.3 \%) \\
26(34.2 \%)\end{array}$ & $\begin{array}{l}12(15.8 \%) \\
34(44.7 \%)\end{array}$ & 0.160 \\
\hline Aperistalsis & $\begin{array}{l}\text { Yes } \\
\text { No }\end{array}$ & $\begin{array}{c}3(4.0 \%) \\
27(35.5 \%)\end{array}$ & $\begin{array}{c}5(6.6 \%) \\
41(53.9 \%)\end{array}$ & 0.988 \\
\hline Frequent failure & $\begin{array}{l}\text { Yes } \\
\text { No }\end{array}$ & $\begin{array}{c}3(4.0 \%) \\
27(35.5 \%)\end{array}$ & $\begin{array}{c}2(2.6 \%) \\
44(57.9 \%)\end{array}$ & 0.644 \\
\hline Jackhammer & $\begin{array}{l}\text { Yes } \\
\text { No }\end{array}$ & $\begin{array}{c}0(0 \%) \\
30(39.5 \%)\end{array}$ & $\begin{array}{c}1(1.3 \%) \\
45(59.2 \%)\end{array}$ & 0.605 \\
\hline $\begin{array}{l}\text { Nutcracker } \\
\text { esophagus }\end{array}$ & $\begin{array}{l}\text { Yes } \\
\text { No }\end{array}$ & $\begin{array}{c}1(1.3 \%) \\
29(38.2 \%)\end{array}$ & $\begin{array}{c}2(2.6 \%) \\
44(57.9 \%)\end{array}$ & 0.658 \\
\hline GEJ obstruction & $\begin{array}{l}\text { Yes } \\
\text { No }\end{array}$ & $\begin{array}{c}3(4.0 \%) \\
27(35.5 \%)\end{array}$ & $\begin{array}{c}0(0 \%) \\
46(60.5 \%)\end{array}$ & 0.058 \\
\hline $\begin{array}{l}\text { Rapid } \\
\text { contraction }\end{array}$ & $\begin{array}{l}\text { Yes } \\
\text { No }\end{array}$ & $\begin{array}{c}1(1.3 \%) \\
29(38.2 \%)\end{array}$ & $\begin{array}{c}2(2.6 \%) \\
44(57.9 \%)\end{array}$ & 0.658 \\
\hline $\begin{array}{l}\text { Esophageal } \\
\text { Spasm }\end{array}$ & $\begin{array}{l}\text { Yes } \\
\text { No }\end{array}$ & $\begin{array}{c}2(2.6 \%) \\
28(36.8 \%)\end{array}$ & $\begin{array}{c}1(1.3 \%) \\
45(59.2 \%)\end{array}$ & 0.342 \\
\hline Unclassified & $\begin{array}{l}\text { Yes } \\
\text { No }\end{array}$ & $\begin{array}{c}9(11.8 \%) \\
22(28.9 \%)\end{array}$ & $\begin{array}{l}13(17.1 \%) \\
32(42.1 \%)\end{array}$ & 0.547 \\
\hline
\end{tabular}

In our study, achalasia was noted in 8 patients with GERD $(10.5 \%)$. Nutcracker esophagus mainly presents with acid reflux symptoms. ${ }^{12}$ In our study, the nutcracker esophagus was noted in 3 cases $(3.9 \%)$. The least common motility disorder noted in these patients was Jackhammer esophagus seen in 1 patient $(1.3 \%)$.

However, no standardized treatment protocol exists for the management of these motility disorders. ${ }^{13}$ Treatment for achalasia revolves around pneumatic dilation, hellers myotomy or botulinum toxin injection. ${ }^{14}$ While for DES or Jackhammer the use of calcium channel blockers, nitrates and phosphodiaesterase inhibitors are advised. While most cases of GEJ outflow obstruction resolve on its own or in a subset of patients are managed like achalasia. ${ }^{14}$ Our patients were managed on these modes.

\section{Limitations of the study}

The major limitation of the current study was that 22 patients $(28.9 \%)$ remained unclassified even after applying the Chicago classification. Even though the Chicago classification system has led to an improvement in our understanding and the management of esophageal motility disorder ${ }^{15}$ the classification system needs be expanded in the near future to include these patients. Further refinement in the Chicago classification is needed to remove the ambiguity and to improve the diagnostic criteria for these disorders. ${ }^{16}$

Also, patients having post-surgical problems along with UES abnormalities could be included in this classification scheme. ${ }^{15}$

\section{CONCLUSION}

A significant number of patients with GERD have motility disorders the early identification and treatment of which leads to improvement in symptoms. Our study is one of the few done on this topic from Asia and is the first such study from Pakistan and opens up further avenues for managing these patients.

\section{What is already known}

1. GERD patients suffer from motility disorders

2. Lack of identification leads to mismanagement and overtreatment.

What does this study add?

1. Our study highlights the prevalence of the motility disorder in GERD patients from Pakistan

2. One of the few studies highlighting the presence of motility disorders in GERD patients.

\section{REFERENCES}

1. Katz PO, Gerson LB and Vela MF. Guidelines for the diagnosis and management of gastroesophageal reflux disease. Am J Gastroenterol. 2013;108(3):308-328; quiz 329. Epub 2013 Feb 19. Erratum in: Am J Gastroenterol. 2013 Oct;108(10):1672.

https://doi.org/10.1038/ajg.2012.444

2. Atkins D, Briss PA, Eccles M, Flottorp S, Guyatt GH, Harbour RT, et al. Systems for grading the quality of evidence and the strength of recommendations II: pilot study of a new system. BMC Health Serv Res. 2005; 5:25-36.

https://doi.org/10.1186/1472-6963-5-25

3. Vakil N, van Zanten SV, Kahrilas P Dent J and Jones R. Global Consensus Group. The Montreal definition and classification of gastroesophageal reflux disease: a global evidence-based consensus. Am J Gastroenterol. 2006; 101:1900-1920.

https://doi.org/10.1111/j.1572-0241.2006.00630.x

4. Dent J, El-Serag HB, Wallander MA and Johansson S. Epidemiology of gastro-oesopha- geal reflux disease: a systematic review. Gut. 2005; 54:710-717.

https://doi.org/10.1136/gut.2004.051821

5. Karim S, Jafri W, Faryal A, Majid S, Salih M, Jafri F, et al. Regular post dinner walk; can be a useful lifestyle modification for gastroesophageal reflux. J Pak Med Assoc. 2011;61(6):526-530.

6. Jafri $\mathrm{N}$, Jafri $\mathrm{W}$, Yakoob J, Islam $M$, Manzoor $\mathrm{S}$, Jalil $\mathrm{A}$, et al. Perception of gastroesophageal reflux disease in urban population in Pakistan. J Coll Physicians Surg Pak. 2005;15(9):532-534.

7. Grande M, Grande S, Campanelli M and Lisi G. Esophageal Motility Disorders in Gastroesophageal Reflux Disease. JSM Gastroenterol Hepatol. 2016 4(2): 1057.

8. Kasamatsu S, Matsumura T, Ohta Y, Hamanaka S, Ishigami H, Taida T, et al. The Effect of Ineffective Esophageal Motility on Gastroesophageal Reflux Disease. Digestion. 2017;95(3):221-228. Epub 2017 Mar 25. https://doi.org/10.1159/000468925

9. Ribolsi $M$, Balestrieri $P$, Biasutto $D$, Emerenziani $S$ and Cicala M. Role of Mixed Reflux and Hypomotility with Delayed 
Reflux Clearance in Patients with Noncardiac Chest Pain. J Neurogastroenterol Motil. 2016; 22(4): 606-612.

https://doi.org/10.5056/jnm15182

10. Deepalakshmi K, Vasanthi R, Venkatakrishnan Land Karthikeyan S. Clinical and manometric profile of patients with GERD in a tertiary care hospital. Int J Adv Med. 2017; 4:1658-1661. https://doi.org/10.18203/2349-3933.ijam20175185

11. Bognár L, Horváth ÖP and Vereczkei A. GERD: A debated background of achalasia. New Horizons in Clinical Case Reports. 2017; 1:8-9.

https://doi.org/10.1016/j.nhccr.2017.06.154

12. Börjesson $M$, Pilhall $M$, Rolny $P$ and Mannheimer $C$ Gastroesophageal acid reflux in patients with nutcracker esophagus. Scand J Gastroenterol. 2001;36(9):916-920. https://doi.org/10.1080/003655201750305413

13. Lacy BE and Weiser K. Esophageal motility disorders: medical therapy. J Clin Gastroenterol. 2008;42(5):652-658. https://doi.org/10.1097/MCG.0b013e31815bd223

14. Kahrilas PJ, Bredenoord AJ, Carlson DA and Pandolfino JE. Advances in Management of Esophageal Motility Disorders. Clin Gastroenterol Hepatol. 2018;16(11):1692-1700. https://doi.org/10.1016/j.cgh.2018.04.026

15. Rohof WOA and Bredenoord AJ. Chicago Classification of Esophageal Motility Disorders: Lessons Learned. Curr Gastroenterol Rep. 2017;19(8):37. https://doi.org/10.1007/s11894-017-0576-7

16. Yadlapati R, Kahrilas PJ, Fox MR, Bredenoord AJ, Prakash Gyawali C, Roman S, et al. Esophageal motility disorders on high-resolution manometry: Chicago classification version 4.0@. Neurogastroenterol Motil. 2021;33(1): e14058. https://doi.org/10.1111/nmo.14058

Authors' contributions:

ZM- Concept and design of the study, Manuscript preparation- first draft; SML, MMH- Performed the manometry; FH- Manuscript preparation- second draft;

AAT-Performed the data analysis; NHL- Final corrections.

Work attributed to:

Department of Gastroenterology, Sindh Institute of Urology and Transplantation, SIUT, Karachi, Pakistan

Orcid ID:

Zain Majid- (1) https://orcid.org/0000-0002-6961-3011

Source of Funding: None, Conflict of Interest: None. 